\title{
THERAPEUTIC EFFICACY OF CHITOSAN NANOPARTICLES LOADED WITH ALBENDAZOLE ON PARENTERAL PHASE OF EXPERIMENTAL TRICHINELLOSIS
}

\section{By}

NASHAAT E. NASSEF ${ }^{1}$, ISMAIL M. MOHARM ${ }^{1 *}$, AMANY F. ATIA ${ }^{1}$, REHAM M. BRAKAT ${ }^{1}$, NOHA M. ABOU HUSSIEN ${ }^{1}$ AND ASMAA SHAMSELDEEN ${ }^{2 *}$ Department of Medical Parasitology ${ }^{1}$, and Department of Pathology ${ }^{2}$, Faculty of Medicine, Menoufia University, Shebin el-Kom, Menoufia, Egypt (Correspondence: *drismail_moharm@yahoo.com;**asmaashams@rocketmail.com)

\section{Abstract}

Most of the drugs used for trichinellosis treatment showed a limited bioavailability, a high degree of resistance and a weak activity against encapsulated larvae. Therefore, there is an urgent need to develop new agents to improve the bioavailability of these drugs. So, the aim of the present study was to assess the use of chitosan $(\mathrm{CH})$ nanoparticles alone or loaded with full and half dose albendazole (ABZ) to increase albendazole dissolution rate, to enhance its antiparasitic activity during the muscular phases of $T$. spiralis infection. Fifty male albino mice were used. They were divided into six experimental groups. Two control groups each includes five mice and four infected treated groups each includes ten mice. Chitosan nanoparticles were used orally at a dose of $100 \mathrm{mg} / \mathrm{kg} /$ day starting from the $31^{\text {st }}$-day post infection (dpi) for seven successive days either alone or loaded with full dose or half dose of ABZ. Results revealed a significant improvement in all treated groups with the highest reduction rate (97.3\%) of muscle larval counts, improvement of muscular histopathological changes, and degeneration of encysted larvae with minimal pathologic changes of infected skeletal muscles. A significant decrease in inducible nitric oxide synthetize (iNOS) expression in muscle tissues was in mice treated by $\mathrm{CH}$ loaded with a full dose of $\mathrm{ABZ}$ compared to control group.

Keywords: Albendazole- Chitosan, Nanoparticles, Nitric oxide, Trichinella spiralis

\section{Introduction}

Trichinella spiralis (T. spiralis) is a nematode parasite that infects about 11 million people worldwide (Murrell and Pozio, 2011), particularly in the Mediterranean region and African countries (Pozio, 1991) In Egypt, it was reported in man (Abdel-Hafeez et al, 2015) and in slaughtered pigs in Cairo Abattoirs (Morsy et al, 2000).

Generally, Trichinellosis is a serious foodborne parasitic zoonosis caused by eating the raw or undercooked pig meats contaminated with the Trichinella spiralis encysted larvae (Gottstein et al, 2009). Its life cycle consists of two phases; enteral and muscular (Abou Rayia et al, 2017). Within the skeletal muscles, the larvae induce the myocyte to transform into a new cell type called nurse cell, which maintains the life of the larvae for months or even up to years (Despommier, 2009). Heavy infection causes serious muscle pain and other complications or even death (Taratuto and Venturiello, 1997).
The commonly used drugs for trichinellosis are benzimidazole derivatives as albendazole $^{(\mathrm{R})}$, flubendazole ${ }^{(\mathrm{R})}$, mebendazole ${ }^{(\mathrm{R})}$, or thiabendazole $^{(\mathrm{R})}$ (McKellar and Scott, 1990). These drugs have a better outcome at the stage of intestinal invasion. However, when included in conventional pharmaceutical forms, these drugs fail to be effective to kill the muscle encysted larvae (Pozio et al, 2001) or the newborn larvae of $T$. spiralis (Saad et al, 2016). They have a high degree of resistance and a weak activity against encapsulated larvae (Garcia et al, 2014).

The nanoparticles have been used widely in previous studies as vehicles to deliver drugs or vaccines to improve their therapeutic efficacy (Jiang et al, 2013; Gaafar et al, 2014). Chitosan ( $\mathrm{CH})$ is a natural polysaccharide produced by deacetylation of chitin (Abdel-Latif et al, 2017). It is used in the pharmaceutical applications due to its biocompatibility, nontoxicity, muco-adhesiveness, low immunogenicity and ecological safety 
(Priotti et al, 2017). Multiple approaches aimed at improving $\mathrm{ABZ}$ water solubility and dissolution rates, such as oil/water emulsions (Mingjie et al, 2002), formulation of chitosan microspheres (Abulaihaiti et al, 2015) and microcrystals (Priotti et al, 2017). Also, it was demonstrated that the enhanced bioavailability of the parent drug/ active metabolite correlated with an improved antiparasitic effect (Abulaihaiti et al, 2015).

The present study aimed to increase albendazole dissolution rate to enhance the antiparasitic activity during the muscular phases of $T$. spiralis infection by assessing chitosan nanoparticles loaded with the full and half doses or alone during the T. spiralis muscular phases in experimental infected mice.

\section{Materials and Methods}

A total of 50 laboratory-bred parasites free, male Swiss albino mice weighing 18$20 \mathrm{gm}$ each, were used. Experimental animals were obtained from the animal house of Theodore Bilharz Research Institute, Giza, Egypt. Mice were fed on a standard pellet diet and water ad libitum. The isolate of T. spiralis used was originally obtained from infected pork from the Cairo Governmental Slaughterhouse, and maintained in the laboratory of Medical Parasitology Department, Tanta Faculty of Medicine by consecutive passages in animal model. They were maintained in accordance with the institutional and national guidelines and were kept in the animal house exposed to 12 hours light/12 hours; dark and fed on a standard diet and tap water. Stool examination was done prior to the study to be sure that mice were free from any intestinal parasitic infection. Trichinella isolate used in this study were genotyped as $T$. spiralis by the European Union Reference Laboratory for Parasites, Superior Institute of Health, Rome, Italy. Mice were orally infected with $200 T$. spiralis larvae/mouse (Dunn and Wright, 1985) and maintained in accordance with the institutional and national guidelines.

Drug administration: the Albendazole was purchased as Alzental (Epico). One tablet (100mg) was dissolved in 50ml distilled water and given orally in a dose of $50 \mathrm{mg} / \mathrm{kg} /$ day (Attia et al, 2015). Chitosan nanoparticles: degree of deacetylation $93 \%$. From Sigma-Aldrich, USA, was used as a solution, given orally in a dose $100 \mathrm{mg} / \mathrm{kg} / \mathrm{day}$. Chitosan nanoparticles loaded with either full dose or half dose of ABZ, was administered orally in a dose of $100 \mathrm{mg} / \mathrm{kg} /$ day (Akhtar et al, 2012).

The experimental animals were divided into six groups: GI (control negative) includes 5 mice, GII (control positive) includes 5 mice, GIII (infected treated by ABZ) includes 10 mice, group IV (infected treated by $\mathrm{CH}$ nanoparticles) includes 10 mice, GV (infected treated by $\mathrm{CH}$ nanoparticles loaded with full dose of ABZ) includes 10 mice and GVI (infected treated by $\mathrm{CH}$ nanoparticles loaded with half dose of ABZ) includes 10 mice. Drugs were administrated from 31 days post infection for seven consecutive days. Mice were sacrificed 49 days p.i. for evaluation of the drugs in the muscular phase of infection. Muscle samples were obtained from the hind limb of mice and preserved in $10 \%$ formalin for histopathological and immunohistochemical studies. The remaining muscles of mice were digested for the larval count. Isolated larvae of $T$. spiralis were preserved in glutraldehyde solution for scanning electron microscopic study

T. spiralis larval count in muscles: Each mouse was dissected and digested in $1 \%$ pepsin (1:10.000) and 1\% concentrated HCL in $200 \mathrm{ml}$ distilled water. The mixture was incubated at $37^{\circ} \mathrm{C}$ for an hour under continuous agitation using an electric stirrer. The digested product was passed via a $50 \mathrm{mesh} /$ inch sieve to remove the coarse particles. The encysted larvae were collected on a 200 mesh/inch sieve, washed twice with tap water and then suspended in $150 \mathrm{ml}$ of tap water in a conical flask. The supernatant fluid was then discarded and the sediment larvae were counted microscopically using a McMaster counting chamber (Denham, 1965). Efficacy 
of treatment $(\%)=100 \times$ mean number recovered in controls minus mean number recovered covered in treated mouse/mean number recovered in controls (Ashour et al, 2016).

For histopathological examination, skeletal muscle specimens from the hind legs were taken from mice sacrificed on the $49^{\text {th }}$ dpi (Monib et al, 2010). These specimens were fixed in $10 \%$ formalin, dehydrated, cleared and then embedded in paraffin blocks (Garcia, 2007). Formalin-fixed, paraffin-embedded sections ( $5 \mu \mathrm{m}$ thickness) were prepared and stained with hematoxylin and eosin ( $\mathrm{H} \& \mathrm{E})$. Muscle specimens were examined and sco-red using a semiquantitative score for the skeletal muscle specimens: the number of larvae per low power field was demonstrated and scored as follows: $+1<5$ larvae, $+2=5-10$ larvae, +3 $>10$ larvae. Also, the intensity of the inflammatory reaction surrounding the capsule was evaluated and scored: $+1=$ mild, $+2=$ moderate,$+3=$ intense reaction. For evaluation of the extent of infection and inflammation, these two parameters were used, an examination of 10 low-power fields $(\times 100)$ in each histological section was done with the average score was calculated (Drury and Wallington, 1980).

Immunohistochemical staining of iNOS: The presence of iNOS protein was analyzed by immunohistochemical staining using the avidin-biotin immunoperoxidase complex technique (Ultra vision \& Detection System anti-polyvalent HRP/DAB, ready to use; Thermo Scientific Corporation, USA). Immunohistochemistry was performed according to the manufacturing protocol. Tissue sections $(4 \mu \mathrm{m}$ thick) of the previously formalin-fixed, paraffin-embedded specimens were cut and mounted. The sections were deparaffinized and rehydrated in graded ethanol and endogenous peroxidase was blocked by using 3\% hydrogen peroxide in methanol for 5 minutes (min). For antigen retrieval, the slides were immersed in a citrate buffer and put in the microwave for $8 \mathrm{~min}$.
Samples were then incubated for an hour at room temperature with iNOS (Rabbit Polyclonal Antibody; Thermo Scientific Corporation) at a dilution of 1:100. After the application of a secondary antibody, slides were developed using 3-3'-diaminobenzidine chromogenic and counterstained with hematoxylin. Negative control slides were made by omitting the primary antibody. Sections from the lung were stained as a positive control (Attia et al, 2015).

Evaluation of iNOS expression: iNOS immune stains were assessed microscopically in 10 high power field (HPF) (x400) in each tissue section. Positive cells for iNOS show brownish cytoplasmic staining that was semi-quantitatively scored based on the percentage of positive cells as follows: 0 (0$9 \%),+1$ (10-49\% positive cells), +2 (50$89 \%$ positive cells), +3 ( $>90 \%$ positive cells). Staining intensity was graded as follows: 0 (no staining), +1 : weak, +2 : moderate $\&+3$ : strong. The final scores were calculated by multiplying the quantity score with intensity score, divided by 3 , with a range from 0 to 9 . A score of 7-9 was considered a strong immune-reactivity $(+3)$; 4$6=$ moderate $(+2) ; 1-3=$ weak $(+1)$; and $0=$ negative (Ravn et al, 1993; Lee et al, 2008).

SEM: Worms were directly pipetted into a fresh fixation solution of $2.5 \%$ glutaraldehyde $(\mathrm{w} / \mathrm{v})$ in $0.1 \mathrm{M}$ sodium cacodylate at pH 7.2 and left overnight at $3{ }^{\circ} \mathrm{C}$. Worms were washed in $0.1 \mathrm{M}$ sodiumcacodylate buffer at $\mathrm{pH} 7.2$ for $5 \mathrm{~min}$, post-fixed in a $2 \%(\mathrm{w} / \mathrm{v})$ osmium-tetroxide in sodium cacodylate buffer for $1 \mathrm{hr}$. Specimens were dehydrated in an ethanol series, dried in liquid carbon dioxide and mounted on a stub. After sputter coating with gold, was examined by Jeol microscope (Jeol Corp., Mitaka, Japan).

Statistical analysis: Data were tabulated and analyzed by SPSS version 22.0 on IBM compatible computer. Quantitative values of the measured parameters were expressed as mean \pm standard deviation (SD). MannWhitney test (non-parametric test) tested the significance between the two groups without 
normal distributed quantitative variables. Probability of significant differences was determined by chi-square $\left(\chi^{2}\right)$ test. Difference was considered significant when $\mathrm{P}$ $<0.05$, highly significant when $p<0.01$ and not significant when $\mathrm{p}>0.05$.

\section{Results}

The total larval count in all treated groups showed a significant difference (Tab. 1), as each compared to control non-treated group $(\mathrm{P}<0.001)$. The highest reduction of the total larval count was achieved by chitosan nanoparticles loaded with a full dose of albendazole $(97.3 \%)$, followed by the infected group that was treated with chitosan nanoparticles loaded with a half dose of albendazole $(96.7 \%)$. While in GIII the larval count reduction was $71.3 \%$. The lowest reduction was detected in GIV treated with chitosan nanoparticles $(60.9 \%)$.

Muscles of infected control group showed many encysted $T$. spiralis larvae $(+3)$ each surrounded by a thick intact capsule with intense inflammatory infiltrate formed mainly of lymphocytes and macrophages with fat deposition (Fig. 1a). Most of infected mice that were treated with ABZ (80\%) showed a moderate degree of larval deposition $(+2)$ with a significant difference between GIII and each of GIV, GV \& GVI (P10 $=0.02$, $\mathrm{P} 11=0.007, \mathrm{P} 12=0.02)$ respectively. Most of larvae showed fragmentation, homogenization (replaced by eosinophilic material) and invasion by inflammatory cellular infiltrate. Capsules around most of the larvae showed thinning in some areas (Fig. 1b). $\mathrm{CH}$ treated (GIV) showed a dense larval deposition $(+3)$ with degeneration of the larvae in the form of fragmentation and invasion by inflammatory cellular infiltrate (Fig. 1c). There was a significant difference between GIV and each treated group (Tabs. $2 \& 3$ ). The lowest intensity of larval deposition in muscular tissue was noticed in group treated with $\mathrm{CH}$ nanoparticles loaded with full dose of ABZ $(\mathrm{GV})$ as eight mice out of ten recorded +1 scores $(80 \%)$ with degeneration of the larvae in the form of fragmentation, vacuolation, and invasion by inflammatory cellular infiltrate (Fig. 1d). The same findings were observed in the group treated with $\mathrm{CH}$ nanoparticles loaded with a half dose of ABZ (GVI) but with higher intensity of larval deposition in the muscular tissue while, no significant difference between both GV\& GVI (P15=0.61).

Immunohistochemical expression of iNOS in the muscular tissues of infected control revealed strong staining $(+3)$ in the inflammatory cellular infiltrate around the capsule (Fig. 2a). Eight of ten of infected mice were treated with ABZ $(80 \%)$ showed moderate degree of iNOS expression (+2) (Fig. 2b) with higher significant differences between this group and each treated group (GIV, GV $\&$ GVI $(\mathrm{P} 10=0.02, \mathrm{P} 11<0.001, \mathrm{P} 12=0.004)$ respectively (Tab. 4). Chitosan treated group showed the highest degree of iNOS expression among all treated groups (Fig. 2c). Lowest intensity of iNOS expression (80\%) was noticed in the group treated with $\mathrm{CH}$ nanoparticles loaded with a full dose of ABZ (GV) as two mice out of ten recorded negative iNOS expression (20\%) and 8/10 mice showed weak expression +1 . This revealed mild staining $(+1)$ in inflammatory cellular infiltrate around capsule (Fig. 2d). Mice treated with $\mathrm{CH}$ nanoparticles loaded with a half dose of ABZ (GVI) showed a higher score of iNOS expression without significant difference (P15=0.08). No significant difference was between mice received $\mathrm{CH}$ loaded with $\mathrm{ABZ}$ full dose or $\mathrm{CH}$ loaded with a half dose of $\mathrm{ABZ}$ as to the histopathological or immunohistochemical changes.

SEM in infected untreated group showed cuticle with normal morphology (Fig. 3a). Marked destruction was in all treated groups with more destruction in that treated by $\mathrm{CH}$ loaded with a full dose of ALB (GV). Cuticle showed areas with marked swellings, multiple large blebs, fissures and vesicles with loss of normal creases, ridges, and annulations of cuticle. Sloughing of some areas of cuticle was observed (Fig. 3 b).

Details were given in tables and figures 
Table 1: Comparison between the groups regarding larval count.

\begin{tabular}{|c|c|c|c|c|c|}
\hline group & $\mathrm{M} \pm \mathrm{SD}$ & Range & Reduction $\%$ & Mann Whitney test & $\mathrm{P}$ value of mean \\
\hline $\begin{array}{l}\text { GI (control -ve) } \\
(\mathrm{n}=5)\end{array}$ & No & No & No & $\begin{array}{l}\text { II versus III }=3.08 \\
\text { II versus IV }=3.11\end{array}$ & $\begin{array}{l}\mathrm{P} 1=0.002 * \\
\mathrm{P} 2=0.002 *\end{array}$ \\
\hline $\begin{array}{l}\text { GII (control +ve) } \\
(\mathrm{n}=5)\end{array}$ & $280200.0 \pm 3408.2$ & $221000-300000$ & $0 \%$ & $\begin{array}{l}\text { II versus } \mathrm{V}=3.47 \\
\text { II versus VI =3.11 }\end{array}$ & $\begin{array}{l}\mathrm{P} 3=0.001 * * \\
\mathrm{P} 4=0.001 * *\end{array}$ \\
\hline $\begin{array}{l}\text { GIII (infected TTT } \\
e^{\prime} \text { ABZ) }(n=10)\end{array}$ & $80360.0 \pm 56807.9$ & $9400-140100$ & $71.3 \%$ & $\begin{array}{l}\text { III versus IV }=0.91 \\
\text { III versus V }=3.73\end{array}$ & $\begin{array}{l}\mathrm{P} 5=0.36 \\
\mathrm{P} 6<0.001 * *\end{array}$ \\
\hline Larval count & Reduction \% & Mann Whitney test & $\mathrm{P}$ value of mean & $\begin{array}{l}\text { III versus } \mathrm{VI}=3.57 \\
\text { IV versus } \mathrm{V}=3.99\end{array}$ & $\begin{array}{l}\mathrm{P} 7<0.001 * * \\
\mathrm{P} 8<0.001 * *\end{array}$ \\
\hline $\mathrm{M} \pm \mathrm{SD}$ & Range & $6200-20201$ & $97.3 \%$ & $\begin{array}{l}\text { IV versus VI }=3.82 \\
V \text { versus IV } b=3.19\end{array}$ & $\begin{array}{l}\mathrm{P} 9<0.001 * * \\
\mathrm{P} 10=0.001 * *\end{array}$ \\
\hline
\end{tabular}

Table 2: Histopathological examination of muscular tissues of all groups regarding larval count.

\begin{tabular}{|c|c|c|c|c|c|}
\hline Groups & Larval deposition intensity & Larval depos & $\%$ in muscles & $\chi^{2}$ test & $\mathrm{P}$ value \\
\hline GI (control - ve) $(n=5)$ & 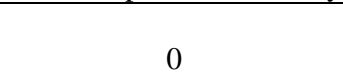 & $\begin{array}{l}\text { No. } \\
5\end{array}$ & $\begin{array}{r}\% \\
100\end{array}$ & $\begin{array}{l}\text { I versus II }=10.0 \\
\text { I versus III }=15.0\end{array}$ & $\begin{array}{l}\mathrm{P} 1=0.007 * \\
\mathrm{P} 2=0.002 *\end{array}$ \\
\hline GII (control +ve) $(n=5)$ & $\begin{array}{l}+2 \\
+3\end{array}$ & $\begin{array}{l}1 \\
4\end{array}$ & $\begin{array}{l}20.0 \\
80.0\end{array}$ & $\begin{array}{l}\text { I versus IV }=15.0 \\
\text { I versus } V=15.0\end{array}$ & $\begin{array}{l}\mathrm{P} 3=0.001 * * \\
\mathrm{P} 4=0.001 * *\end{array}$ \\
\hline $\begin{array}{l}\text { GIII (infected TTT with } \\
\text { ABZ) }(n=10)\end{array}$ & $\begin{array}{l}+1 \\
+2 \\
+3 \\
\end{array}$ & $\begin{array}{l}1 \\
8 \\
1\end{array}$ & $\begin{array}{l}10.0 \\
80.0 \\
10.0\end{array}$ & $\begin{array}{l}\text { I versus } \mathrm{VI}=15.0 \\
\text { II versus } \mathrm{III}=7.40 \\
\text { II versus } \mathrm{IV}=0.17\end{array}$ & $\begin{array}{l}\mathrm{P} 5=0.001^{* *} \\
\mathrm{P} 6=0.02^{*} \\
\mathrm{P} 7=0.68\end{array}$ \\
\hline $\begin{array}{l}\text { GIV (infected TTT with } \\
\text { CH) }(n=10)\end{array}$ & $\begin{array}{l}+2 \\
+3\end{array}$ & $\begin{array}{l}3 \\
7\end{array}$ & $\begin{array}{l}30.0 \\
70.0\end{array}$ & $\begin{array}{l}\text { II versus } \mathrm{V}=12.0 \\
\text { II versus } \mathrm{VI}=11.63\end{array}$ & $\begin{array}{l}\mathrm{P} 8=0.002^{*} \\
\mathrm{P} 9=0.003 *\end{array}$ \\
\hline $\begin{array}{l}\text { GV (infected TTT with } \\
\mathrm{CH}+\text { full ABZ) }(\mathrm{n}=10)\end{array}$ & $\begin{array}{l}+1 \\
+2 \\
\end{array}$ & $\begin{array}{l}8 \\
2\end{array}$ & $\begin{array}{l}80.0 \\
20.0\end{array}$ & $\begin{array}{l}\text { III versus IV }=7.77 \\
\text { III versus V }=10.04\end{array}$ & $\begin{array}{l}\mathrm{P} 10=0.02^{*} \\
\mathrm{P} 11=0.007^{*}\end{array}$ \\
\hline $\begin{array}{l}\text { GVI (infected TTT with } \\
\mathrm{CH}+\text { half ABZ) }(\mathrm{n}=10)\end{array}$ & $\begin{array}{l}+1 \\
+2\end{array}$ & $\begin{array}{l}7 \\
3\end{array}$ & $\begin{array}{l}70.0 \\
30.0\end{array}$ & $\begin{array}{l}\text { III versus } V I=7.77 \\
\text { IV versus } V=15.20 \\
\text { IV versus } V I=14.00 \\
V \text { versus } V I=0.27\end{array}$ & $\begin{array}{l}\mathrm{P} 12=0.02 * \\
\mathrm{P} 13=0.001 * * \\
\mathrm{P} 14=0.001 * * \\
\mathrm{P} 15=0.61\end{array}$ \\
\hline
\end{tabular}

Table 3: Histopathological examination of muscular tissues of groups regarding inflammatory reaction intensity.

\begin{tabular}{|c|c|c|c|c|c|}
\hline Groups & Inflammation degree & Inflamm & $\mathrm{y}$ intensity & \multirow{7}{*}{$\begin{array}{l}\chi^{2} \text { test } \\
\text { I versus II }=10.0 \\
\text { I versus } \mathrm{III}=15.0 \\
\text { I versus IV }=15.0 \\
\text { I versus } \mathrm{V}=15.0 \\
\text { I versus } \mathrm{VI}=15.0 \\
\text { II versus III }=7.40 \\
\text { II versus IV }=0.17 \\
\text { II versus } \mathrm{V}=12.00 \\
\text { II versus } \mathrm{VI}=11.40 \\
\text { III versus } \mathrm{IV}=7.77 \\
\text { III versus } \mathrm{V}=10.04 \\
\text { III versus } \mathrm{VI}=6.71 \\
\text { IV versus } \mathrm{V}=15.20 \\
\text { IV versus } \mathrm{VI}=13.14 \\
\mathrm{~V} \text { versus } \mathrm{VI}=0.95\end{array}$} & \multirow{7}{*}{$\begin{array}{l}\mathrm{P} \text { value } \\
\mathrm{P} 1=0.007^{*} \\
\mathrm{P} 2=0.002^{*} \\
\mathrm{P} 3=0.001^{* *} \\
\mathrm{P} 4=0.001^{* *} \\
\mathrm{P} 5=0.001^{* *} \\
\mathrm{P} 6=0.02 * \\
\mathrm{P} 7=0.68 \\
\mathrm{P} 8=0.002^{*} \\
\mathrm{P} 9=0.003^{*} \\
\mathrm{P} 10=0.02^{*} \\
\mathrm{P} 11=0.007^{*} \\
\mathrm{P} 12=0.04 * \\
\mathrm{P} 13=0.001 * * \\
\mathrm{P} 14=0.001 * * \\
\mathrm{P} 15=0.33\end{array}$} \\
\hline GI $(n=5)$ & 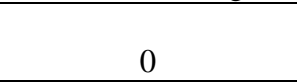 & $\begin{array}{c}\mathrm{No} \\
5 \\
\end{array}$ & $\begin{array}{r}\% \\
100 \\
\end{array}$ & & \\
\hline GII $(n=5)$ & $\begin{array}{l}+2 \\
+3 \\
\end{array}$ & $\begin{array}{l}1 \\
4 \\
\end{array}$ & $\begin{array}{l}20.0 \\
80.0\end{array}$ & & \\
\hline GIII $(n=10)$ & $\begin{array}{l}+1 \\
+2 \\
+3\end{array}$ & $\begin{array}{l}1 \\
8 \\
1\end{array}$ & $\begin{array}{l}10.0 \\
80.0 \\
10.0\end{array}$ & & \\
\hline GIV $(n=10)$ & $\begin{array}{l}+2 \\
+3 \\
\end{array}$ & $\begin{array}{l}3 \\
7\end{array}$ & $\begin{array}{l}30.0 \\
70.0\end{array}$ & & \\
\hline $\mathrm{GV}(\mathrm{n}=10)$ & $\begin{array}{l}+1 \\
+2 \\
\end{array}$ & $\begin{array}{l}8 \\
2\end{array}$ & $\begin{array}{l}80.0 \\
20.0\end{array}$ & & \\
\hline GVI $(n=10)$ & $\begin{array}{l}+1 \\
+2\end{array}$ & $\begin{array}{l}6 \\
4\end{array}$ & $\begin{array}{l}60.0 \\
40.0\end{array}$ & & \\
\hline
\end{tabular}

Table 4: iNOS expression in muscular tissues in all groups.

\begin{tabular}{|c|c|c|c|c|c|}
\hline Group & iNOS expression intensity & iNOS & ression\% & $\chi^{2}$ test & \multirow{8}{*}{$\begin{array}{l}\quad \text { P value } \\
\text { P1 }=0.007^{*} \\
\text { P2 }=0.001 * * \\
\text { P3 }=0.001^{* *} \\
\text { P4 }=0.003^{*} \\
\text { P5 }=0.001^{* *} \\
\text { P6 }=0.02^{*} \\
\text { P7 }=0.68 \\
\text { P8 }=0.002^{*} \\
\text { P9 }=0.003^{*} \\
\text { P10 }=0.02^{*} \\
\text { P11 }<0.001^{* *} \\
\text { P12 }=0.004^{*} \\
\text { P13 }<0.001^{* *} \\
\text { P14 }=0.001^{* *} \\
\text { P15 }=0.08\end{array}$} \\
\hline GI (control -ve) $(n=5)$ & 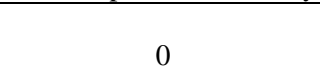 & $\begin{array}{l}\mathrm{No} \\
5\end{array}$ & $\begin{array}{c}\% \\
100\end{array}$ & \multirow{7}{*}{$\begin{array}{l}\text { I versus II }=10.0 \\
\text { I versus III }=15.0 \\
\text { I versus IV }=15.0 \\
\text { I versus } \mathrm{V}=8.57 \\
\text { I versus VI }=15.0 \\
\text { II versus III }=5.00 \\
\text { II versus IV }=0.17 \\
\text { II versus } V=15.0 \\
\text { II versus VI }=11.63 \\
\text { III versus IV }=5.05 \\
\text { III versus V }=20.0 \\
\text { III versus } V=11.27 \\
\text { IV versus } V=20.0 \\
\text { IV versus } V=14.00 \\
V \text { versus } V I=5.07\end{array}$} & \\
\hline GII (control +ve) $(\mathrm{n}=5)$ & $\begin{array}{l}+2 \\
+3\end{array}$ & $\begin{array}{l}1 \\
4\end{array}$ & $\begin{array}{l}20.0 \\
800\end{array}$ & & \\
\hline GIII (infected TTT with & +2 & 8 & 80.0 & & \\
\hline ABZ) $(n=10)$ & +3 & 2 & 20.0 & & \\
\hline $\begin{array}{l}\text { GIV (infected TTT with } \\
\mathrm{CH})(\mathrm{n}=10)\end{array}$ & $\begin{array}{l}+2 \\
+3 \\
\end{array}$ & $\begin{array}{l}3 \\
7\end{array}$ & $\begin{array}{l}30.0 \\
70.0\end{array}$ & & \\
\hline $\begin{array}{l}\text { GV (infected TTT with } \\
\mathrm{CH}+\text { full ABZ) }(\mathrm{n}=10)\end{array}$ & $\begin{array}{c}0 \\
+1\end{array}$ & $\begin{array}{l}2 \\
8\end{array}$ & $\begin{array}{l}20.0 \\
80.0\end{array}$ & & \\
\hline $\begin{array}{l}\text { GVI (infected TTT with } \\
\mathrm{CH}+\text { half } \mathrm{ABZ})(\mathrm{n}=10)\end{array}$ & $\begin{array}{l}+1 \\
+2\end{array}$ & $\begin{array}{l}7 \\
3\end{array}$ & $\begin{array}{l}70.0 \\
30.0\end{array}$ & & \\
\hline
\end{tabular}




\section{Discussion}

The commonly used drugs for the treatment of trichinellosis are effective against $T$. spiralis adults with no or low effects on the encysted larvae in muscles (Kukhaleva et al, 2015). Albendazole is extensively used to treat intestinal parasites due to its extended spectrum activity and low cost (Priotti et al, 2017). But, it showed a high degree of resistance and weak activity against encapsulated larvae (Solana et al, 2009).

The present results revealed that the group treated with chitosan nanoparticles loaded with a full dose of albendazole $(\mathrm{GV})$ gave a high reduction percentage of larval count $(97.3 \%)$. This may be due to the microcrystals made with chitosan which appear to be the best options to optimize oral absorption of the active pharmaceutical ingredient designed to improve albendazole dissolution rate in treating $T$. spiralis infected mice during the intestinal phase of the parasite cycle (Garcia et al, 2013). Also, it was wellknown that the smaller the particle size, the larger the surface area and the faster the dissolution rate of drug particles (Priotti et al, 2017).

In the present study, larval count reduction with albendazole was $71.3 \%$. This agreed with Siriyasatien et al. (2003); Shalaby et al. (2010) and Abou Rayia et al. (2016). The mild effect of albendazole on encysted larvae may be attributed to the fact that once the larvae were encysted in muscle tissues, therapeutic intervention is not feasible as their susceptibility to chemotherapies diminishes with the infection duration (Yadav and Temjenmongla, 2006; 2012). But, Attia et al. (2015) reported that larvae reduction was $90.9 \%$. The lowest larval count reduction $(60.9 \%)$ was in the group treated with chitosan nanoparticles. However, there was a significant difference $(\mathrm{P} 2=0.002)$ between this group and the control one in the mean of larval count. These results were in harmony with Hoseini et al. (2016), Abdel-Latif et al. (2017) and El-Dek et al. (2019) who used loaded chitosan particles for other parasites. Chitosan has the ability to penetrate and adhere to the intestinal mucosa inducing intestinal mastocytosis, goblet cells hyperplasia and mucin 2 expressions (Tho-ngborisute $e t$ $a l, 2006)$. The increased mucosal mast cells count and mucus secretion trapped adult worms and expel them (Khan et al, 1995).

In the present study, the lowest inflammation intensity and the lowest larval deposition were infected mice treated with chitosan nanoparticles loaded with a full dose of albendazole. There was marked decrease in histopathological changes including the inflammatory cellular infiltrate compared to infected untreated ones. Most of the infected mice treated with albendazole showed a moderate degree of inflammation and a moderate degree of larval deposition, but mice treated with chitosan nanoparticles alone showed the highest degree of inflammation and of larval deposition among all treated groups. The histopathological changes agreed with Shalaby et al. (2010) and Abou Rayia et al. (2016). Control of inflammation reduced systemic cytokine release from activated immune cells, which relieved clinical pictures like the fever, tissue edema and vasculitis (Kociecka, 2000).

In the present study, the lowest intensity of iNOS expression was in infected mice treated with chitosan nanoparticles loaded with albendazole full dose. Also, most of the infected mice treated with albendazole showed a moderate degree of iNOS expression with higher significant differences. But, chitosan treated group showed the highest degree of iNOS expression among all treated groups. These results agreed with others who studied iNOS expression in mice infected with $T$. spiralis (Yu et al, 2013; Attia et al, 2015). Also, the stimulatory effect of ALB on enzymes involved in oxygen and nitrogen free radical-based host defense (iNOS) in trichinellosis was reported (Boczon et al, 2004; Zeromski et al, 2005). This explains the iNOS expression in ALB treated groups. In the 
present study, the effects of chitosan on iNOS expression agreed with Li et al. (2009).

Increasing the activity of iNOS and induced synthesis of NO in macrophages were influenced by chitosan (Porporatto et al, 2003; Yu et al, 2004). This explained the severe inflammation and the strong iNOS expression in the chitosan treated groups. The NO is identified as an important effector molecule that limits the pathogens in the infected hosts by playing a role in tissue pathology (Ashour et al, 2016). Host tissue damage in the muscle phase of trichinellosis was not only caused by the invading parasite but also by inflammatory cells that produce high re-active oxygen species levels and several stress markers as iNOS (Abou Rayia et al, 2016).

In the present study, by SEM all treated groups showed changes in $T$. spiralis adults and larvae structures. But more changes were in chitosan loaded with the albendazole full dose treated mice. Destruction of larvae led to decrease in toxin produced by them that stimulated the immune system and decreased the cellular infiltration causing muscles' pathological changes. These results were not surprising as transcuticular passive diffusion was the principal mechanism of drug entry into helminthiasis (Thompson and Geary, 1999). The cuticular changes are good indicator for the anti-helminthic drug activity (Gaafar et al, 2014; Abou Rayia et $a l, 2016)$. The changes in the shape of the organisms may be secondary to changes from interference of the drugs with DNA synthesis of the parasite or interference with folic acid cycle (Hammouda et al, 1992).

\section{Conclusion}

Both combined drugs of chitosan nanoparticles loaded either with full or half doses of albendazole caused the highest reduction rate in larval counts. They caused improvement in histopathological lesions, mild iNOS expression and marked degeneration of encysted larvae better results than albendazole alone. Chitosan nanoparticles loaded with albendazole represented a promising drug for treatment of $T$. spiralis encysted larvae in host muscles.

\section{References}

Abdel-Hafeez, EH, Kamal, AM, Abdelgelil, N H, Abdel-Fatah, M, 2015: Parasites transmitted to human by ingestion of different types of meat, El-Minia City, El-Minia Governorate, Egypt. J. Egypt. Soc. Parasitol. 45, 3:671-80.

Abdel-Latif, M, El-Shahawi, G, Aboelhadid, SM, Abdel-Tawab, H, 2017: Immunoprotective effect of Chitosan particles on Hymenolepis nana-infected mice. Scand. J. Immunol. 86, 2:8390.

Abou Rayia, DM, Saad, AE, Ashour, DS, Oreiby, RM, 2017: Implication of artemisinin nematocidal activity on experimental trichinellosis: In vitro and in vivo studies. Parasitol. Int. 66, 2: 56-63.

Abulaihaiti, M, Wu, XW, Qiao, L, Lv, HL, Zhang HW, et al, 2015: Efficacy of Albendazole-Chitosan microsphere-based treatment for alveolar echinococcosis in mice. PLoS Negl. Trop. Dis. 9, e0003950.

Akhtar, F, Rizvi, MM, Kar, SK, 2012: Oral delivery of curcumin bound to chitosan nanoparticles cured Plasmodium yoelii infected mice. Biotechnol. Adv. 30, 1:310-20.

Ashour, DS, Abou Rayia, DM, Saad, AE, ElBakary, RH, 2016: Nitazoxanide anthelmintic activity against the enteral and parenteral phases of trichinellosis in experimentally infected rats. Exp. Parasitol. 170:28-35.

Attia, RA, Mahmoud, AE, Farrag, HM, Makboul, R, Mohamed, ME, et al, 2015: Effect of myrrh and thyme on Trichinella spiralis enteral and parenteral phases width inducible nitric oxide expression in mice. Mem. Inst. Oswaldo Cruz 110, 8:1035-41.

Boczon, K, Wandurska-Nowak, E, Wierzbicki, A, Frydrychowic, M, Moser, I, et al, 2004: mRNA expression and immunohistochemical localization of inducible nitric oxide synthase (NOS-2) in the muscular niche of Tri-chinella spiralis. Folia Histochem. Cytobiol. 42: 209-13.

Denham, DA, 1965: Studies with methyridine and Trichinella spiralis. I. Effect upon the intestinal phase in mice. Exp. Parasitol.17, 1:10-4.

Despommier, DD, 2009: Trichinellida, Dioctophymatida and Enoplean Parasites, Ch.23. In: Foundations of Parasitology, $8^{\text {th }}$ ed. McGrawHill companies, Inc., New York.

Drury, AA, Wallington, EA, 1980: Carleton's 
histological technique, $5^{\text {th }}$ edn. Oxford University Press, New York.

Dunn, IJ, Wright, KA, 1985: Cell injury caused by Trichinella spiralis in the mucosal epithelium of B10A mice. J. Parasitol. 71, 6:757-66 El-Dek, SI, Hassan, IM, Mohammed, AF, Khalil, A, 2019: Apoptotic and necrotic effects of chitosan nanoparticles loaded with the honeybee, Apis mellifera venom on different cancer cell lines. J. Egypt. Soc. Parasitol. 49, 1:115-22

Gaafar, MR, Mady, RF, Diab, RG, Shalaby, TI, 2014: Chitosan and silver nanoparticles: Promising anti-toxoplasma agents. Exp. Parasitol.143:30-8.

Garcia, LS, 2007: Diagnostic Medical Parasitology, $5^{\text {th }}$ Ed., ASM Press, Washington, USA

Garcia, A, Barrera, MG, Piccirilli, G, Vasconi, MD, Di Masso, RJ, et al, 2013: Novel albendazole formulations given during the intestinal phase of Trichinella spiralis infection reduce effectively parasitic muscle burden in mice. Parasitol. Int. 62, 6:568-70.

Garcia, A, Leonardi, D, Vasconi, MD, Hinrichsen, LI, Lamas MC, 2014: Characterization of albendazole-randomly methylated- $\beta$-cyclodextrin inclusion complex and in vivo evaluation of its anthelminthic activity in a murine model of trichinellosis. PLoS One 9:e113296.

Gottstein, B, Pozio, E, Nockler, K, 2009: Epidemiology, diagnosis treatment and control of trichinellosis. Clin. Microbiol. Rev. 22:127-45.

Hammouda, NA, El-Gebali, WM, Razek, M K, 1992: Intestinal parasitic infection among sewage workers in Alexandria, Egypt. J. Egypt. Soc. Parasitol. 22, 2:299-303.

Hoseini, MH, Moradi, M, Alimohammadian, MH, Shahgoli, VK, Darabi, H, et al, 2016: Immunotherapeutic effects of chitin in comparison with chitosan against Leishmania major infection. Parasitol. Int. 65, 2:99-104.

Jiang, S, Hua, E, Liang, M, Liu, B, Xie, G, 2013: A novel immunosensor for detecting Toxoplasma gondii-specific IgM based on goldmag nanoparticles and grapheme sheets. Colloids Surface B: Biointerfaces 101:481-6.

Khan, WL, Abe, T, Ishikawa, N, Nawa, Y, Yoshimura, K, 1995: Reduced amount of intestinal mucus by treatment with anti-CD4 antibody interferes with the spontaneous cure of $\mathrm{Ni}$ ppostrongylus brasiliensis infection in mice. Parasite Immunol. 17:485-91.

Kociecka, W, 2000: Trichinellosis: human disease, diagnosis and treatment. Vet. Parasitol. 93:
365-83.

Kolodziej-Sobocinska, M, Dvoroznakova, E, Dziemian, E, 2006: Trichinella spiralis: macrophage activity and antibody response in chronic murine infection. Exp. Parasitol. 112, 1:52-62.

Kukhaleva, I.V, Kovalenko, FP, Shkolyar, N A, Legonkov, YA, Musaev, AKh, et al, 2015: Therapeutic activity of micronized mebendazole in the muscular phase of experimental Trichinella spiralis invasion in albino mice. Meditsin. Parazitol. Parazitar. Bolezni 4:36-9.

Lee, LY, Chi-Ming, W, Wang, CC, Song, JY, Liang Y, et al, 2008: Expression of matrix metalloproteinases MMP-2 andMMP-9 in gastric cancer and their relation to claudin-4 expression. Histol. Histopathol. 23:515-21.

Li, HY, Yan, SM, Shi, BL, Guo, XY, 2009: Effect of chitosan on nitric oxide content and inducible nitric oxide synthase activity in serum and expression of inducible nitric oxide synthase mRNA in small intestine of broiler chickens. Asian-Aust. J. Anim. Sci. 22, 7:1048-53.

McKellar, QA, Scott, EW, 1990: The benzimidazole anthelmintic agents: A review. J. Vet. Pharmacol. Therap. 13, 3:223-47.

Mingjie, W, Shuhua, X, Junjie, C, Bin, L, Cheng, F, et al, 2002: Albendazole-soybean oil emulsion for the treatment of human cystic echinococcosis: evaluation of bioavailability and bioequivalence. Acta Trop. 83:177-81.

Monib, MEM, Shaheen, MS, Galal, LA, Farrag, HM, 2010: Role of $T$. spiralis adult and larval antigens in immunomodulation of nitric oxide (NO) in intestinal and muscular phase of trichinelosis. Assiut Med. J. 34:147-58.

Morsy, TA, Ibrahim, BB, Haridy, FM, Rifaat, MM, 2000: Trichinella encysted larvae in slaughtered pigs in Cairo (1995-1999). J. Egypt. Soc. Parasitol. 30, 3:753-60.

Murrell, KD, Pozio, E, 2011: Worldwide occurrence and impact of human trichinellosis, 19862009. Emerg. Infect. Dis. 17, 12:2194-202.

Othman, AA, Abou Rayia, DM, Ashour, DS, Saied, EM, Zineldeen, DH, et al, 2016: Atorvastatin and metformin administration modulates experimental Trichinella spiralis infection. Parasitol. Int. 65, 2:105-12.

Porporatto, C, Bianco, ID, Riera, CM, Corres, SG, 2003: Chitosan induces different L-arginine metabolic pathways in resting and inflammatory macrophages. Biochem. Biophys. Res. Commun. 304, 2:266-72.

Pozio, E, 1991: Current status of food-borne 
parasitic zoonoses in Mediterranean and African regions. Southeast Asian J. Trop. Med. Publ. Hlth. 22:S85-7.

Pozio, E, Sacchini, D, Sacchi, L, Tamburrini, A, Alberici, F, 2001: Failure of mebendazole in the treatment of humans with Trichinella spiralis infection at the stage of encapsulating larvae. Clin. Infect. Dis. 32, 4:638-42.

Priotti, J, Codina, AV, Leonardi, D, Vasconi, MD, Hinrichsen, LI, et al, 2017: Albendazole microcrystal formulations based on chitosan and cellulose derivatives: Physicochemical characterization and in vitro parasiticidal activity in Trichinella spiralis adult worms. AAPS Pharm. Sci. Tech. 18, 4:947-56.

Ravn, V, Rasmussen, BB, Hojholt, L, 1993: Reproducibility of subjective immunohistochemical estrogen- and progesterone receptor determination in human endometrium. Pathol. Res. Pract. 189:1015-22.

Saad, AE, Ashour, DS, Abou Rayia, DM, Bedeer, AE, 2016: Carbonic anhydrase enzyme as a potential therapeutic target for experimental trichinellosis. Parasitol. Res. 115, 6:2331-9.

Shalaby, MA, Moghazy, FM, Shalaby, HA, Nasr, SM, 2010: Effect of methanolic extract of Balanites aegyptiaca fruits on enteral and parenteral stages of Trichinella spiralis in rats. Parasitol. Res. 107:17-25.

Siriyasatien, P, Yingyourd, P, Nuchprayoon, S, 2003: Efficacy of albendazole against early and late stage of Trichinella spiralis infection in mice. J. Med. Assoc. Thailand 86, 2: 257-62.

Solana, H, Scarcella, S, Virkel, G, Ceriani, C,
Rodriguez, J, et al, 2009: Albendazole enantiomeric metabolism and binding to cytosolic proteins in the liver fluke Fasciola hepatica. Vet. Res. Commun. 33, 2:163-73.

Taratuto, AL, Venturiello, SM, 1997: Trichi nosis. Brain Pathol. 7, 1:663-72.

Thompson, D, Geary, T, 1995: The structure and function of helminth surfaces. In: Biochemistry and Molecular Biology of Parasites. JJ, Marr, M, Muller (Eds.), Academic, London, UK.

Thongborisute, J, Takeuchi, H, Yamamoto, H, Kawashima, Y, 2006: Visualization of the penetrative and mucoadhesive properties of chitosan and chitosan-coated liposomes through the rat intestine. J. Liposome Res. 16:127-41

Yadav, AK, Temjenmongla, A, 2012: Efficacy of Lasia spinosa leaf extract in treating mice infected with Trichinella spiralis. Parasitol. Res. 110:493-8.

Yadav, AK, Temjenmongla, A, 2006: Anti-helminthic activity of Gynura angulosa DC against Trichinella spiralis infections in mice. PhOL 2: 299-306.

Yu, YR, Deng, MJ, Lu, WW, Jia, MZ, Wu, W, et al, 2013: Systemic cytokine profiles and splenic toll-like receptor expression during Trichinella spiralis infection. Exp. Parasitol. 134, 1:92-101.

Yu, Z, Zhao, L, Ke, H, 2004: Potential role of nuclear factor-kappa B in the induction of nitric oxide and tumor necrosis factor-alpha by oligochitosan in macrophages. Int. Immunopharmacol. 4, 2:193-200.

\section{Explanation of figures}

Fig. 1: a: TS in skeletal muscle of GII (infected none treated) shows heavy larval deposition (green arrows) (+3) within muscle fibers surrounded by intense inflammatory reaction (yellow arrows) $(+3)$ and thick capsule $(C)$ with fat deposition (blue arrow) in between muscle fibers (H\&E) (x200); b: TS in skeletal muscle of GIII (infected treated by ABZ) shows moderate larval deposition (green arrow) (+2) within muscle fibers surrounded by moderate inflammatory reaction (yellow arrow) $(+2)$ and homoginization and dissolving of parts from encysted larvae (D) (H\&E; x200); c: TS in skeletal muscle of GIV (infected treated by $\mathrm{CH}$ ) shows heavy larval deposition (green arrow) $(+3)$ within muscle fibers surrounded by dense inflammatory reaction (yellow arrows) (+3) (H\&E; x200) and d: TS in skeletal muscle of GV (infected treated by $\mathrm{CH}+$ full $\mathrm{ABZ}$ ) shows mild larval deposition (yellow arrow) $(+1)$ within muscle fibers surrounded by mild inflammatory reaction (green arrows) (+1) with intact muscle fibers (M), thin capsule (C) and disintgration of encysted larva (red arrow) (H\&E; x200).

Fig. 2: (a): TS in skeletal muscle of GII (infected none treated) stained e' immunohistochemical stain shows, strong iNOS (+3) expression (blue arrows) within inflammatory cells and nurse cells and multiple granulomas (yellow arrows) (x100); (b): TS in skeletal muscle of GIII (infected treated by ABZ) stained with immunohistochemical stain shows, moderate iNOS (+2) (yellow arrow) expression within inflammatory cells and nurse cells surrounding multiple granulomas (red arrows) (x200); (c): TS in skeletal muscle of GIV (infected treated by $\mathrm{CH}$ ) stained with immunohistochemical stain shows, strong iNOS (+3) (red arrows) expression within inflammatory cells and nurse cells and multiple granulomas (white arrow) with thick capsule (C) (x200) and (d): TS in skeletal muscle of GV (infected treated by $\mathrm{CH}+$ full ABZ) stained with immunohistochemical stain shows, mild iNOS (+1) (red arrow) expression within inflammatory cells and nurse cells with thin capsule (yellow arrow) (x200).

Fig. 3: a: TS of T. spiralis larva of an infected control mice shows, fine longitudinal ridges (L) and transverse creases (C) seen b: S.T. of $T$. spiralis larva of an infected treated with $\mathrm{CH}+$ full $\mathrm{ABZ}$ shows sloughing and destruction of cuticle (yellow arrows) with multiple fissures (red arrow) with loss of cuticle normal annulations (green arrow). 


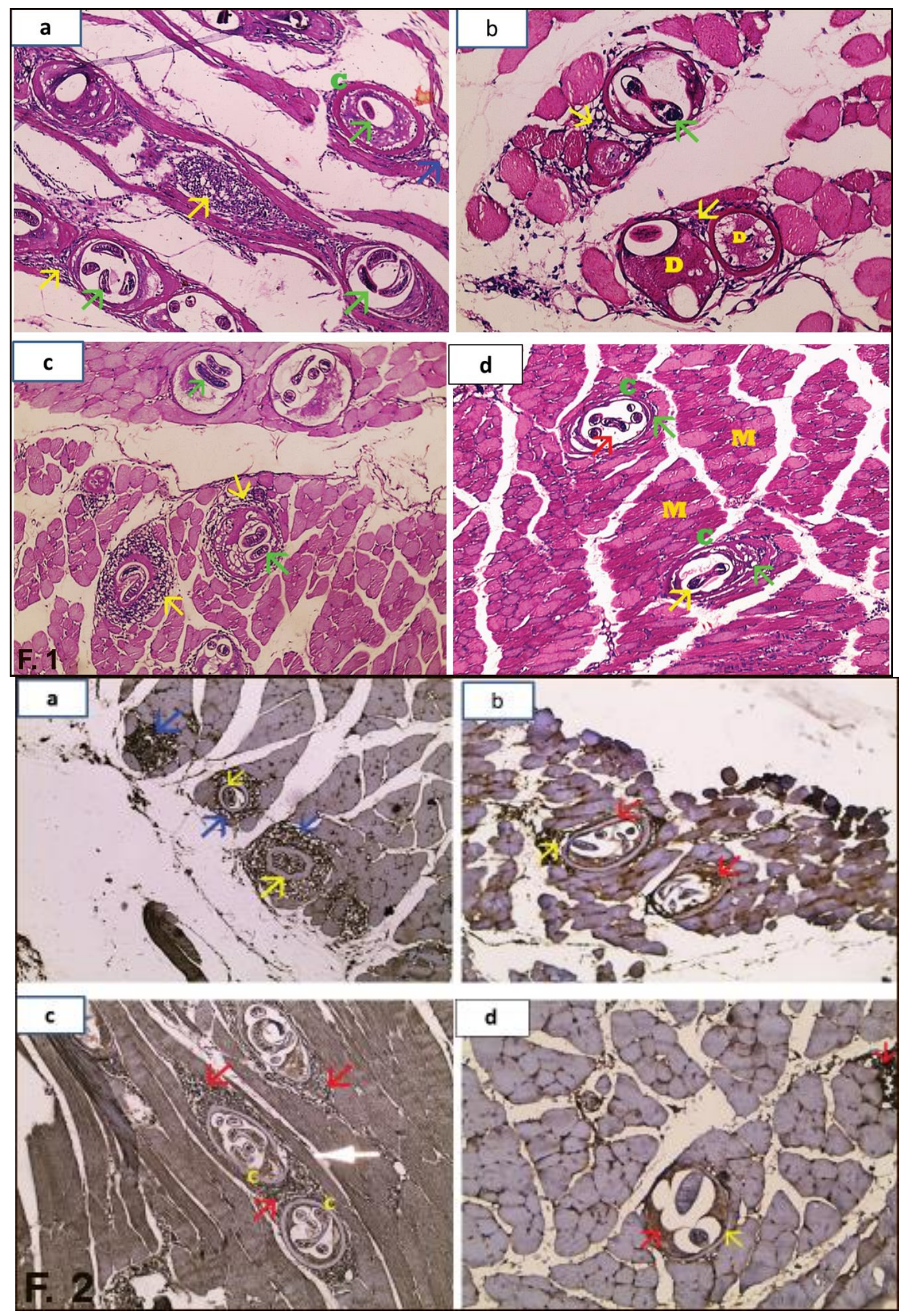




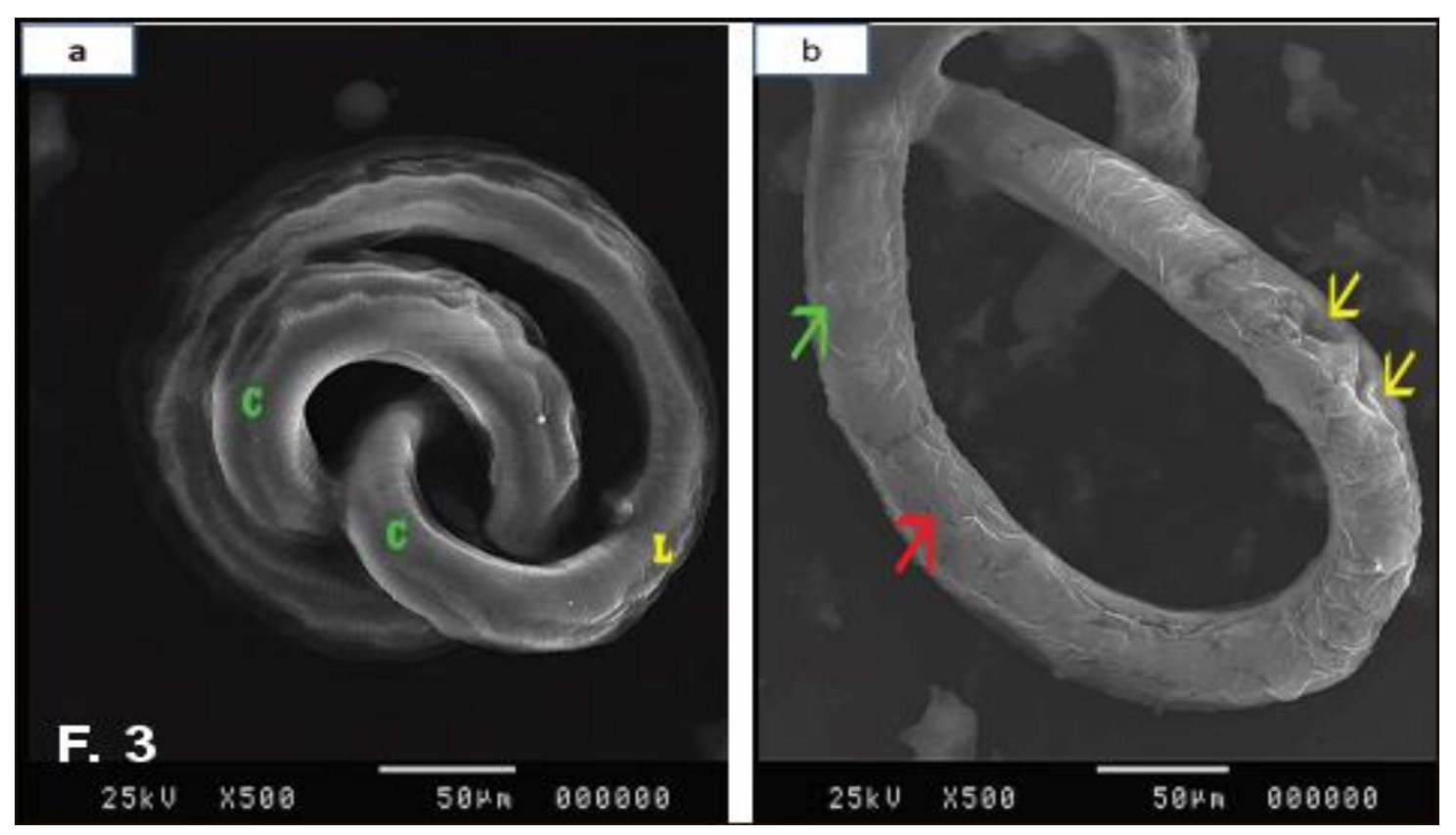

